\title{
Nitrogen Metabolism in a New Obligate Methanotroph, 'Methylosinus' Strain 6
}

\author{
By ARESA E. TOUKDARIAN $\dagger$ AND MARY E. LIDSTROM* $\ddagger$ \\ Department of Microbiology and Immunology, SC-42, University of Washington, Seattle, \\ Washington 98195, USA
}

(Received 7 September 1983; revised 13 February 1984)

\begin{abstract}
A new obligate methanotroph was isolated and characterized. It was classified as a 'Methylosinus' species and named 'Methylosinus' sp. strain 6. Nitrogen metabolism in 'Methylosinus' 6 was found to be similar to other Type II methanotrophs, including the assimilation of nitrogen exclusively by the glutamine synthetase/glutamate synthase system. However, unlike other Type II methanotrophs, it appeared that glutamine synthetase activity was regulated by adenylylation in this organism. 'Methylosinus' 6 was grown in continuous culture with either dinitrogen or nitrate as sole nitrogen source under various dissolved oxygen tensions. Higher rates of methane oxidation and a more developed intracytoplasmic membrane system were found at lower oxygen tensions with nitrate as the nitrogen source but at higher oxygen tensions with dinitrogen as the nitrogen source. This suggested that carbon metabolism was influenced by nitrogen metabolism in this organism.
\end{abstract}

\section{INTRODUCTION}

During the past 20 years a substantial body of information has accumulated on carbon and energy metabolism in methanotrophs, while studies on nitrogen metabolism have been limited (Wolfe \& Higgins, 1979; Higgins et al., 1981; Anthony, 1982). The emphasis on carbon metabolism is understandable as it is the ability of methanotrophs to utilize reduced one-carbon compounds for growth which distinguishes them from other bacteria. However, studies on nitrogen metabolism are essential for a complete understanding of the physiology of this ecologically and commercially important group of microbes.

The separation of methanotrophs into two types was originally based on the appearance of the intracellular membrane system found in all isolates (Whittenbury et al., 1970). This division was supported by subsequent studies of carbon metabolism in methanotrophs (Lawrence \& Quayle, 1970; Davey et al., 1971). A number of recent studies indicate that differences in nitrogen metabolism in methanotrophs may be correlated with the Type I-Type II classification scheme.

The ability to fix nitrogen is characteristic of all Type II methanotrophs studied and is present in only a few Type I organisms, all of which have been Methylococcus species, and which may actually belong to a third group, Type X, (Bailey et al., 1978; Whittenbury \& Dalton, 1981; Murrell \& Dalton, 1983c). In addition, the mode of ammonia assimilation found in a given methanotroph during growth on different inorganic nitrogen compounds is consistent with that organism's classification as a Type I or Type II methanotroph (Shiskina \& Trotsenko, 1979; Murrell \& Dalton, 1983b). Although the association of certain aspects of nitrogen metabolism with a specific type of carbon metabolism may simply reflect evolutionary divergence of Type I

$\dagger$ Present address: AFRC Unit of Nitrogen Fixation, University of Sussex, Brighton BN1 9RQ, UK.

$\ddagger$ Formerly Mary L. O’Connor.

Abbreviations: DOT, dissolved oxygen tension; GOGAT, glutamate synthase; GS, glutamine synthetase; MMO, methane monooxygenase; SVPDE, snake venom phosphodiesterase. 
and Type II methanotrophs, it may also be indicative of a link between carbon and nitrogen metabolism in these organisms.

We have studied nitrogen metabolism in a new Type II obligate methanotroph, 'Methylosinus' sp. strain 6. This paper describes the isolation and characterization of 'Methylosinus' 6 and an investigation into the relationship between nitrogen and carbon metabolism in this organism.

\section{METHODS}

Strains and media. The culture of Methylobacterium organophilum R6 used in this study was obtained from Dr R. Patel, Exxon Co., Annandale, N.J., USA. MMS, a modification of the mineral salts medium described by Whittenbury et al. (1970), contained per litre of distilled water: $\mathrm{MgSO}_{4} .7 \mathrm{H}_{2} \mathrm{O}, 0.2 \mathrm{~g} ; \mathrm{CaCl}_{2} .2 \mathrm{H}_{2} \mathrm{O}, 0.02 \mathrm{~g}$; $\mathrm{K}_{2} \mathrm{HPO}_{4}, 0.28 \mathrm{~g} ; \mathrm{NaH}_{2} \mathrm{PO}_{4} .1 \mathrm{H}_{2} \mathrm{O}, 0.07 \mathrm{~g}$; tetrasodium EDTA, $50 \mathrm{mg} ; \mathrm{FeSO}_{4} .7 \mathrm{H}_{2} \mathrm{O}, 2 \mathrm{mg} ; \mathrm{ZnSO}_{4} .7 \mathrm{H}_{2} \mathrm{O}$, $0.1 \mathrm{mg} ; \mathrm{MnCl}_{2} .4 \mathrm{H}_{2} \mathrm{O}, 30 \mu \mathrm{g} ; \mathrm{H}_{3} \mathrm{BO}_{3}, 0.3 \mathrm{mg} ; \mathrm{CoCl}_{2} . \mathrm{H}_{2} \mathrm{O}, 0.2 \mathrm{mg} ; \mathrm{CuCl}_{2} .2 \mathrm{H}_{2} \mathrm{O}, 10 \mu \mathrm{g} ; \mathrm{NiCl}_{2} .6 \mathrm{H}_{2} \mathrm{O}, 20 \mu \mathrm{g}$; $\mathrm{Na}_{2} \mathrm{MoO}_{4} \cdot 2 \mathrm{H}_{2} \mathrm{O}, 30 \mu \mathrm{g} ; \mathrm{pH} 6 \cdot 8$. NMMS medium consisted of $\mathrm{MMS}$ medium plus $1 \mathrm{~g} \mathrm{KNO}$ per litre, and AMMS medium consisted of MMS medium plus $1 \mathrm{~g} \mathrm{NH}_{4} \mathrm{Cl}$ per litre. Phosphate buffer (pH 6.8) was added to a final concentration of $0.4 \mathrm{mM}$ to AMMS medium after autoclaving. In experiments in which the properties of ammonia-, nitrate- and dinitrogen-grown cells were directly compared, $0.4 \mathrm{mM}$-phosphate buffer was added to the MMS (dinitrogen) and NMMS (nitrate) growth media. All agar media were made by supplementing the appropriate liquid medium with $15 \mathrm{~g}$ Bacto agar per litre (Difco).

Sulphate-free medium contained per litre of distilled water; $\mathrm{MgCl}_{2} .6 \mathrm{H}_{2} \mathrm{O}, 0.16 \mathrm{~g} ; \mathrm{CaCl}_{2} .2 \mathrm{H}_{2} \mathrm{O}, 0.02 \mathrm{~g}$; $\mathrm{K}_{2} \mathrm{HPO}_{4}, 0.23 \mathrm{~g} ; \mathrm{NaH}_{2} \mathrm{PO}_{4}, 0.07 \mathrm{~g}$; tetrasodium EDTA, $50 \mathrm{mg} ; \mathrm{FeCl}_{2} .4 \mathrm{H}_{2} \mathrm{O}, 1.4 \mathrm{mg} ; \mathrm{ZnCl}, 50 \mu \mathrm{g}$; $\mathrm{MnCl}_{2} .4 \mathrm{H}_{2} \mathrm{O}, 30 \mu \mathrm{g} ; \mathrm{H}_{3} \mathrm{BO}_{3}, 0.3 \mathrm{mg}, \mathrm{CoCl}_{2} .6 \mathrm{H}_{2} \mathrm{O}, 0.2 \mathrm{mg} ; \mathrm{CuCl}_{2} .2 \mathrm{H}_{2} \mathrm{O}, 10 \mu \mathrm{g} ; \mathrm{NiCl}_{2} .6 \mathrm{H}_{2} \mathrm{O}, 20 \mu \mathrm{g}$; $\mathrm{Na}_{2} \mathrm{MoO}_{4} \cdot 2 \mathrm{H}_{2} \mathrm{O}, 30 \mu \mathrm{g} ; \mathrm{pH}$ 6.8. Foster \& Davis salts medium has been described elsewhere (Foster \& Davis, 1966).

For determining the growth characteristics of 'Methylosinus' 6 the following were added singly or in combination to NMMS medium : sodium succinate, $0 \cdot 1 \%(\mathrm{w} / \mathrm{v}) ; 95 \%$ ethanol, $0 \cdot 1 \%(\mathrm{v} / \mathrm{v})$; sodium acetate, $10 \mathrm{mM}$; glucose, $10 \mathrm{~mm}$; yeast extract, $0.005 \%(\mathrm{w} / \mathrm{v})$; Casamino acids, $0.02 \%(\mathrm{w} / \mathrm{v})$; and vitamin supplement (Lynch et al., 1980). All additions were sterilized separately and then added directly to the autoclaved growth medium.

Nutrient agar and nutrient broth were purchased from Difco.

Cultural conditions. 'Methylosinus' 6 was routinely grown on MMS, NMMS or AMMS medium either in liquid culture (with shaking) or on agar plates under an atmosphere of $80 \%$ methane and $20 \%$ air at $30{ }^{\circ} \mathrm{C}$.

To determine which amino acids could be utilized as sole nitrogen source, 'Methylosinus' 6 was inoculated into $35 \mathrm{ml}$ serum vials containing $10 \mathrm{ml}$ MMS medium $+0.1 \% \mathrm{~L}$-amino acids $(\mathrm{w} / \mathrm{v})$ under an atmosphere of $10 \% \mathrm{O}_{2}$ and $90 \% \mathrm{CH}_{4}$. The absence of $\mathrm{N}_{2}$ in the atmosphere was verified by analysing the gas composition. Vials were incubated at $30{ }^{\circ} \mathrm{C}$ with shaking for two weeks before measuring the $\mathrm{OD}_{600}$ of the culture. The amount of growth was determined by comparison with control vials containing $0 \cdot 1 \% \mathrm{NH}_{4} \mathrm{Cl}, 0 \cdot 1 \% \mathrm{KNO}_{3}$ or no added nitrogen compound.

For determining the effect of oxygen on nitrogen and carbon metabolism, 'Methylosinus' 6 was grown in a $500 \mathrm{ml}$ working volume Virtis Moduculture continuous culture system (Virtis Co., Gardiner, NY, USA) with agitation by magnetic stirring. Sulphate limitation was achieved by growth on sulphate-free medium supplemented with $25 \mu \mathrm{M}-\mathrm{Na}_{2} \mathrm{SO}_{4}$ and, for growth with nitrate as the nitrogen source, with $0 \cdot 1 \% \mathrm{KNO}_{3}$. Methane was supplied in excess. The dissolved oxygen tension in the culture vessel (monitored with a New Brunswick D.O. probe and meter) was controlled by regulating the flow of air into the vessel with a unit designed by the University of Washington Medical Instrument Shop. This unit maintained dissolved oxygen at the set value $\pm 3 \mu \mathrm{M}$. The dilution rate was $0.03 \mathrm{~h}^{-1}$. Under these conditions the $\mathrm{OD}_{600}$ of the culture was approximately 1.0 , and an increase in the inflowing concentration of sulphate resulted in a concomitant increase in the steady-state optical density. Steady state was defined by the maintenance of the $\mathrm{OD}_{600}$ of the culture within $10 \%$ of this value for at least three generation times.

Analyses. Culture medium was analysed for the presence of ammonia using Nessler's reagent (Sigma) and for nitrate or nitrite by diazotization and coupling reactions (Nicholas \& Nason, 1957) after the removal of cells by centrifugation. The lower limit of detection was approximately $12.5 \mu \mathrm{M}$ for ammonia, $3.9 \mu \mathrm{M}$ for nitrate and $1.5 \mu \mathrm{M}$ for nitrite.

The protein concentrations of extracts were estimated by the Lowry method or, for protein concentrations greater than $10 \mathrm{mg} \mathrm{ml}^{-1}$, by the biuret method of Layne (1957). Bovine serum albumin (BSA) was used as the protein standard.

To determine the protein concentration of cell suspensions, a sample of the culture was centrifuged and the pellet resuspended in a known volume of $0.1 \mathrm{M}-\mathrm{NaOH}$. After heating at $80^{\circ} \mathrm{C}$ for $10 \mathrm{~min}$, the solution was neutralized by the addition of a volume of $0.1 \mathrm{M}-\mathrm{HCl}$ equal to the amount of $\mathrm{NaOH}$ used. The protein 
concentration of this mixture was then estimated by the Lowry method using BSA which had also been treated with alkali-acid as the standard.

The concentration of methane, oxygen and dinitrogen in the gas phase of cultures was measured by thermal conductivity on a Carle analytical gas chromatograph (Carle Instruments, Anaheim, Calif., USA) equipped with a $1.83 \mathrm{~m}$ Molecular Sieve 5A column.

Culture turbidity was measured using a Gilford 2400 spectrophotometer at a wavelength of $600 \mathrm{~nm}$.

Preparation of crude extracts and enzyme assays. Cells were harvested by centrifugation, washed twice in $1 \% \mathrm{KCl}$ and the pellet resuspended in an equal volume of $25 \mathrm{~mm}$-imidazole buffer, $\mathrm{pH} 7 \cdot 15$. Cells were disrupted by two passages through a French press at $137 \mathrm{mPa}$ and the lysate was centrifuged at $48400 \mathrm{~g}$ for $30 \mathrm{~min}$ at $2^{\circ} \mathrm{C}$. The supernatant was used for enzyme assays.

Whole cells were used to assay nitrogenase (acetylene reduction), methane oxidation and ribulosebisphosphate carboxylase activities. All assays were done at $30^{\circ} \mathrm{C}$ and reactions were linear for at least $5 \mathrm{~min}(10 \mathrm{~min}$ for the two glutamine synthetase assays).

The following enzymes involved in carbon metabolism were assayed by published methods: hydroxypyruvate reductase [D-glycerate: $\mathrm{NAD}^{+}$oxidoreductase, EC 1.1.1.29] (Large \& Quayle, 1963); serine-glyoxylate aminotransferase [L-serine: glyoxylate aminotransferase, EC 2.6.1..45] (Blackmore \& Quayle, 1970); hexulose phosphate synthase (Dahl et al., 1972); ribulosebisphosphate carboxylase [3-phospho-D-glycerate carboxylyase (dimerizing), EC 4.1.1.39] (Tabita et al., 1978); and methanol dehydrogenase [EC 1.1.99.8] (O'Connor \& Hanson, 1978). Methane oxidation was assayed as methane-dependent oxygen consumption in an oxygen electrode (Rank Bros., Bottisham, UK). Reactions consisted of $1 \mathrm{ml}$ cell suspensions to which $0 \cdot 1 \mathrm{ml}$ methanesaturated MMS medium was added after the endogenous respiration had ceased.

The following ammonia assimilation enzymes were assayed by the methods described by Murrell \& Dalton $(1983 a, b)$ : glutamine synthetase [L-glutamate:ammonia ligase (ADP-forming), EC 6.3.1.2]; $\gamma$-glutamyl transferase activity and biosynthetic activity; glutamate synthase [glutamine: 2-oxoglutarate aminotransferase (NADPH oxidizing), EC 1.4.1.13]; glutamate dehydrogenase [L-glutamate:NAD(P) ${ }^{+}$oxidoreductase, EC 1.4.1.3] aminating and deaminating activities; and alanine dehydrogenase [L-alanine : $\mathrm{NAD}^{+}$oxidoreductase, EC 1.4.1.1] aminating and deaminating activities.

Snake venom phosphodiesterase (SVPDE) treatment of ammonia-grown cell extracts was carried out in a $1 \mathrm{ml}$ reaction volume containing $50 \mathrm{mM}$-imidazole buffer $\mathrm{pH} 7 \cdot 15,2.8 \mathrm{mg}$ cell protein and $5 \mathrm{mg}$ SVPDE (Type IV from Crotalus atrox, Sigma) at $37^{\circ} \mathrm{C}$. A control extract was treated in parallel without SVPDE. At various time intervals, $50 \mu \mathrm{l}$ samples of the treated and untreated extracts were removed into a glutamine synthetase transferase assay mix containing $0.27 \mathrm{mM}-\mathrm{MnCl}_{2}$ or $0.27 \mathrm{mM}-\mathrm{MnCl}_{2}+60 \mathrm{mM}-\mathrm{MgCl}_{2}$, and the activity was assayed as described above.

Nitrogen fixation was estimated using a modification of the acetylene reduction technique described by Dalton \& Whittenbury (1976a). Cell samples ( 1 or $2 \mathrm{ml}$ ) were incubated with shaking in $15 \mathrm{ml}$ serum vials containing $0.5 \%(\mathrm{v} / \mathrm{v})$ methanol under an atmosphere of $10 \%$ air and $90 \%$ helium for $10 \mathrm{~min}$. Acetylene $(0 \cdot 2 \mathrm{ml})$ was then injected and $1.0 \mathrm{ml}$ samples of the gas phase were removed $5,10,15$ and 30 min later. To maintain pressure in the reaction vial, $1.0 \mathrm{ml}$ of a gas mixture, identical in composition to that initially present, was added to the reaction vial after each time point. The rate of ethylene production was linear for at least 30 min under these conditions. The amount of ethylene present in each sample was determined using a Hewlett Packard gas chromatograph (model $5700 \mathrm{~A}$ ) equipped with a $3.17 \mathrm{~mm}$ diameter, $1.83 \mathrm{~m}$ Porapak $\mathrm{R}$ column at $50{ }^{\circ} \mathrm{C}$.

Electron microscopy. For preparation of thin sections, cells were fixed for $2 \mathrm{~h}$ in cold $3 \%(\mathrm{v} / \mathrm{v})$ glutaraldehyde (Taab Co., Reading, UK) in $0 \cdot 1 \mathrm{M}$-cacodylate buffer, $\mathrm{pH} 7 \cdot 2$, embedded in agar blocks, postfixed in $1 \% \mathrm{OsO}_{4}$ in $0.1 \%$ cacodylate buffer for 1-2 h, dehydrated in gradients of ethanol, and embedded in Epon 812 using standard techniques. Sections were stained first with uranyl acetate then with Reynold's lead citrate, before being viewed on a JEM 100B electron microscope.

DNA isolation and $G+C$ determination. 'Methylosinus' 6 cells were lysed by resuspending frozen cell pellets in TE buffer (150 mM-Tris, $100 \mathrm{mm-EDTA}$, pH 8.0) using approximately $10 \mathrm{ml}$ buffer per $0.5 \mathrm{~g}$ wet weight cells. Lysozyme (Sigma) was added to $1 \mathrm{mg} \mathrm{ml}^{-1}$ and the mixture was incubated for $1 \mathrm{~h}$ at $37^{\circ} \mathrm{C}$. Next, pronase (Calbiochem) was added to a final concentration of $0.5 \mathrm{mg} \mathrm{ml}^{-1}$ and the mixture was incubated at $55^{\circ} \mathrm{C}$ for $1 \mathrm{~h}$. Sodium dodecyl sulphate was then added to $5 \%(\mathrm{w} / \mathrm{v})$ and incubation was continued at $55^{\circ} \mathrm{C}$ until visible clearing of the mixture occurred (approximately $2-3 \mathrm{~h}$ further incubation). DNA was extracted from this lysate by the method of Marmur (1961). Purified DNA was first dissolved in a minimal amount of distilled water and then onetenth volume of $10 \times$ TES buffer was added $(1 \times$ TES is $10 \mathrm{~mm}$-Tris, $1 \mathrm{~mm}$-EDTA, $10 \mathrm{~mm}-\mathrm{NaCl}, \mathrm{pH} 8 \cdot 1)$.

Plasmid DNA was isolated from 'Methylosinus' 6 following the method described by Portnoy et al. (1981). Escherichia coli HB101 cellular DNA was kindly provided by P. Totten, Dept of Microbiology, University of Washington, Seattle, Wash., USA.

The mol $\% \mathrm{G}+\mathrm{C}$ of 'Methylosinus' 6 DNA was measured by the thermal melting method (Johnson, 1981) using E. coli $\mathrm{HB} 101 \mathrm{DNA}$ as reference (G $+\mathrm{C}$ content of $51 \mathrm{~mol} \%$ ). 


\section{RESULTS AND DISCUSSION \\ Isolation and characterization}

'Methylosinus' sp. strain 6 was isolated from a mixed culture of the facultative methanotroph Methylobacterium organophilum R6. This culture was purified by repeated transfer of single colonies of the predominant organism onto NMMS plates incubated under an atmosphere of methane $(80 \%)$ and air $(20 \%)$. The organism thus purified grew well on methane and was unable to grow on nutrient agar plates or in nutrient broth. Growth of this isolate was then tested in liquid cultures or on agar plates of NMMS or Foster \& Davis salts medium supplemented with acetate, glucose, ethanol or succinate as carbon source with or without the addition of yeast extract or a vitamin solution, and incubated at atmospheric or reduced oxygen tensions $(20 \%$ air, $80 \%$ helium). The isolate did not grow on any organic substrates other than methane.

The isolate, strain 6, grew in liquid culture of NMMS or Foster \& Davis salts medium under an atmosphere of methane $(80 \%)$ and air $(20 \%)$. There was no growth of strain 6 if helium replaced methane in the gas mixture. Although methanol could be oxidized, growth was not detected on methanol in liquid culture or on agar plates under a variety of cultural conditions including supplying this substrate in the vapour phase. Vitamins or yeast extract were not required for growth on methane and did not enhance the growth of strain 6 . Similarly, succinate or Casamino acids could be added up to $0 \cdot 1 \%$ to cultures with no apparent affect on growth. Strain 6 was therefore tentatively identified as an obligate methanotroph and characterized further.

Strain 6 was a Gram-negative motile rod 1.0-3.0 $\mu \mathrm{m}$ long. It formed rosettes and what appeared to be exospores under a variety of growth conditions. On agar plates it formed round convex colonies $0.5-1.0 \mathrm{~mm}$ in diameter which became tan coloured with time. A complex intracytoplasmic membrane system typical of the Type II membranes, consisting of peripheral membrane pairs, was seen in electron micrographs of thin sections.

Key enzymes for the three major assimilation pathways known to be utilized by bacteria growing on one-carbon compounds were assayed in strain 6 (Table 1). The oxidative enzyme

Table 1. Activities of enzymes of $C_{1}$ metabolism in 'Methylosinus' 6

$$
\text { Enzyme [nmol } \left.\mathrm{min}^{-1}(\mathrm{mg} \text { protein })^{-1}\right]
$$

Methanol dehydrogenase 29

Hydroxypyruvate reductase $\quad 219$

Serine-glyoxylate aminotransferase $\quad 75$

Hexulose phosphate synthase ND

Ribulosebisphosphate carboxylase $\dagger$ ND

ND, Not detectable.

* All values are the average of rates from two or more cell-free extracts or cultures.

† Activity assayed in whole cells.

Table 2. Amino acids utilized as sole nitrogen source by 'Methylosinus' 6

$\begin{array}{cc}\text { Amino acid } & \text { Growth* } \\ \text { Asn } & +++ \\ \text { Gln } & ++++ \\ \text { Leu } & + \\ \text { Met } & + \\ \text { Phe } & + \\ \text { Pro } & + \\ \text { Ser } & + \\ \text { Trp } & +\end{array}$

$*++++, \mathrm{OD}_{600} 0 \cdot 200-0 \cdot 250 ;+++, \mathrm{OD}_{600} 0 \cdot 150-0 \cdot 200 ;+, \mathrm{OD}_{600} 0 \cdot 050-0 \cdot 100$. Cultures with $0 \cdot 1 \%$ $\mathrm{NH}_{4} \mathrm{Cl}$ or $0 \cdot 1 \% \mathrm{KNO}_{3}$ as sole nitrogen source grew to an $\mathrm{OD}_{600}$ of $0 \cdot 200-0 \cdot 300$. Cultures without an added source of fixed nitrogen did not grow. No growth was detected with the following L-amino acids as the sole nitrogen source: Ala, Arg, Asp, Cys, Glu, His, Lys, Thr, Val. 
methanol dehydrogenase and the key enzymes for the serine pathway for the fixation of formaldehyde (hydroxypyruvate reductase and serine-glyoxylate aminotransferase) were found at high levels in cell-free extracts. The key enzymes for the ribulose monophosphate pathway for the fixation of formaldehyde (hexulose phosphate synthase) and the Calvin-Benson cycle for the fixation of carbon dioxide (ribulosebisphosphate carboxylase) were not detected in strain 6 although they were detected in control organisms known to contain the specific pathway.

Total cellular DNA isolated from strain 6 was found to have a mol $\% \mathrm{G}+\mathrm{C}$ of $60 \%$. This organism was also found to carry two plasmids, 80 and $120 \mathrm{MDal}$ in size, as determined by agarose gel electrophoresis. During the course of our studies no function could be ascribed to either of these plasmids nor were they ever spontaneously cured from the population.

Based on these properties and following the taxonomic scheme developed by Whittenbury $e t$ al. (1970), we classified strain 6 as a Type II obligate methanotroph of the group 'Methylosinus'. Since the taxonomy of methanotrophs has not been formalized, no attempts were made to further classify this isolate and so it was named 'Methylosinus' sp. strain 6.

\section{Nitrogen metabolism}

Ammonia, nitrate or dinitrogen could be utilized as a nitrogen source by 'Methylosinus' 6 . The generation time of batch cultures on all three nitrogen compounds was similar, approximately $12 \mathrm{~h}$. A number of amino acids were also utilized as sole nitrogen source (Table 2). 'Methylosinus' 6 could not utilize nitrite as a nitrogen source nor could it grow anaerobically using nitrate as a terminal electron acceptor.

Dinitrogen fixation could be demonstrated in 'Methylosinus' 6 using the acetylene reduction technique if a suitable substrate was used to supply the energy and reducing power required for nitrogenase. In 'Methylosinus' 6, methane oxidation, as measured by substrate-dependent wholecell oxygen consumption, was completely inhibited by acetylene as has been the case with other obligate methanotrophs (Colby et al., 1975; de Bont \& Mulder, 1976; Dalton \& Whittenbury, $1976 a, b)$. Methanol-dependent oxygen uptake was not inhibited by acetylene, so methanol was routinely used to provide energy and reducing power in the acetylene reduction assay. Other compounds were also suitable for use as a source of energy and reducing power in the assay (Table 3). Acetylene reduction activity was found to be sensitive to the oxygen concentration and showed the typical bell-shaped activity profile with respect to oxygen tension (Fig. 1) found in other aerobic diazotrophs including other methanotrophs (Dalton, 1980; Murrell \& Dalton, $1983 c$ ).

In batch culture experiments, acetylene reduction activity could be demonstrated in cells grown on dinitrogen as the sole nitrogen source but not in cells grown on $0.1 \%$ nitrate or $0.1 \%$ ammonia, indicating that nitrogen fixation in 'Methylosinus' 6 was regulated by fixed nitrogen compounds. Batch cultures grown on dinitrogen did not excrete ammonia, nitrate or nitrite into the medium, and cells grown on nitrate did not excrete ammonia. However, batch cultures grown on ammonia did excrete low levels of nitrite (the level of nitrite in mid-exponential phase cultures was less than $0.5 \%$ of the added ammonia). In several methanotrophs, ammonia has been shown to be oxidized to hydroxylamine by the dissimilation enzyme methane

Table 3. Acetylene reduction activity in 'Methylosinus' 6 with various energy sources

\begin{tabular}{lc}
\multicolumn{1}{c}{ Energy source } & $\begin{array}{c}\text { Activity* } \\
\text { [nmol } \mathrm{min}^{-1}(\mathrm{mg} \text { protein })^{-1} \text { ] }\end{array}$ \\
None & $\mathrm{ND}$ \\
Methanol $(0.05 \%)$ & $7 \cdot 8$ \\
Formate $(0.1 \%)$ & $5 \cdot 0$ \\
Formaldehyde $(10 \mathrm{mM})$ & $\mathrm{ND}$ \\
Ethanol $(0.1 \%)$ & 13.9 \\
$\mathrm{H}_{2}$ & $15 \cdot 7$
\end{tabular}

ND, Not detectable.

* Activity was assayed using the energy source noted at a $\mathrm{pO}_{2}$ of 0.02 bar. When activity with $\mathrm{H}_{2}$ as the energy source was being measured, hydrogen gas was used instead of helium in the atmosphere. 


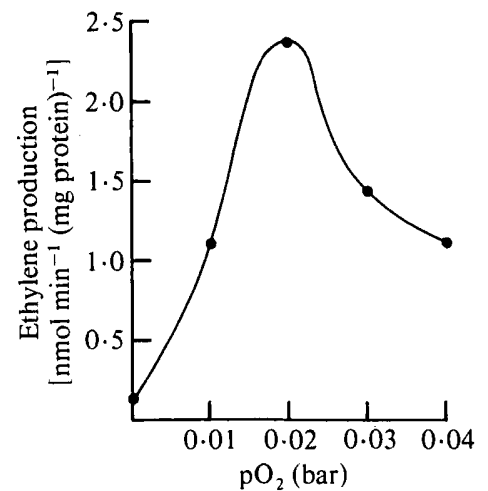

Fig. 1

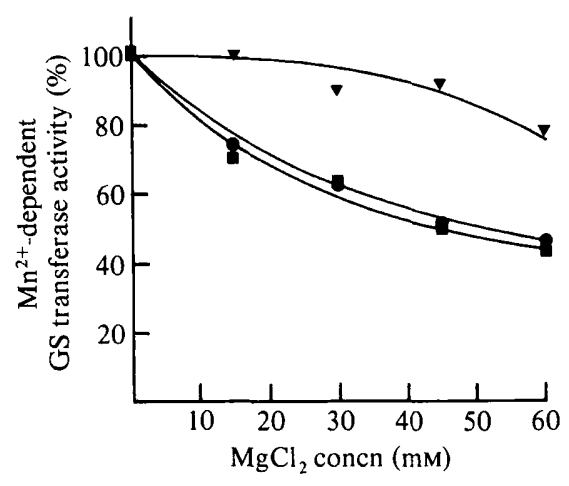

Fig. 2

Fig. 1. Effect of the partial pressure of oxygen $\left(\mathrm{pO}_{2}\right)$ on acetylene reduction activity in 'Methylosinus' 6 . Acetylene reduction activity was assayed in methane-grown 'Methylosinus' 6 in the presence of various concentrations of oxygen (supplied as air) under an atmosphere of hydrogen gas which served as the energy source. Activity profiles of a similar shape were obtained using $0.5 \%$ methanol or $0.1 \%$ formate as the energy source. With these compounds, maximal activity was also obtained at a $\mathrm{pO}_{2}$ of 0.02 bar.

Fig. 2. Inhibition of $\mathrm{Mn}^{2+}$-dependent GS transferase activity by $\mathrm{Mg}^{2+}$. Activity was assayed in cellfree extracts of 'Methylosinus' 6 grown with ammonia $(\square)$, nitrate $(\boldsymbol{O})$ or dinitrogen $(\boldsymbol{\nabla})$ as sole nitrogen source in the presence of varying concentrations of $\mathrm{MgCl}_{2}$. Rates for $100 \%$ activity in the extracts were [nmol $\min ^{-1}$ (mg protein) ${ }^{-1}$ ]: 957 for ammonia-grown cells, 1388 for nitrate-grown cells, and 2543 for dinitrogen-grown cells.

monooxygenase (Dalton, 1977; Drozd et al., 1978; Higgins et al., 1979), followed by the oxidation of hydroxylamine to nitrite or nitrate (Drozd et al., 1978; Sokolov et al., 1980).

\section{Nitrogen assimilation enzymes}

The activities of a number of enzymes involved in ammonia assimilation were determined in cell-free extracts of 'Methylosinus' 6 grown in batch culture with ammonia, nitrate or dinitrogen as sole nitrogen source (Table 4). Aminating or deaminating activities of glutamate dehydrogenase or alanine dehydrogenase were not detected in any cell-free extract (nor were they detected in the pellet obtained after disruption of ammonia- or nitrate-grown cells), while high levels of glutamine synthetase (GS) and glutamate synthase (GOGAT) activities were found in all extracts. This indicated that nitrogen was assimilated in 'Methylosinus' 6 exclusively by way of the GS/GOGAT system, as it apparently is in all Type II methanotrophs previously examined (Shishkina \& Trotsenko, 1979; Murrell \& Dalton, 1983b).

GS activity was measured using both the biosynthetic reaction (possibly the only reaction catalysed by GS in vitro which is of physiological significance) and the $\gamma$-glutamyl transferase reaction (a simpler and more commonly used assay) (Stadtman \& Ginsburg, 1974). The level of $\mathrm{Mg}^{2+}$-dependent GS biosynthetic activity was influenced by the nitrogen source used for growth. Extracts from 'Methylosinus' 6 cells grown with dinitrogen had activity 20 -fold higher than ammonia- or nitrate-grown cells (Table 4). $\mathrm{Mn}^{2+}$-dependent biosynthetic activity was present in all three extracts.

All extracts showed high levels of $\mathrm{Mn}^{2+}$-dependent GS transferase activity, which could be inhibited by the addition of $\mathrm{Mg}^{2+}$ to the assay mix. The level of inhibition depended on the concentration of $\mathrm{Mg}^{2+}$ added, but at all $\mathrm{Mg}^{2+}$ concentrations the inhibition was significantly higher in extracts from ammonia- and nitrate-grown cells than in extracts from dinitrogengrown cells (Fig. 2).

Variability of the $\mathrm{Mg}^{2+}$-dependent GS biosynthetic activity with nitrogen source has not been observed in other Type II methanotrophs (Murrell \& Dalton, 1983b), but has been observed in a number of other bacteria (Ginsburg et al., 1970; Janssen et al., 1980; Lepo et al., 1982) including the Type I methanotroph Methylococcus capsulatus Bath (Murrell \& Dalton, 
Table 4. Activities of ammonia assimilation enzymes in 'Methylosinus' 6

Specific activity was determined in cell-free extracts, except for acetylene reduction which was measured in whole cells. Values represent the average from three different extracts or whole-cell cultures. No glutamate dehydrogenase or alanine dehydrogenase deaminating or aminating activity was detected.

\begin{tabular}{|c|c|c|c|c|c|}
\hline \multirow[b]{2}{*}{ Enzyme } & \multirow[b]{2}{*}{ Cofactor } & \multirow[b]{2}{*}{$\begin{array}{l}\text { Divalent } \\
\text { cation }\end{array}$} & \multicolumn{3}{|c|}{$\begin{array}{c}\text { Specific activity } \\
\left.\left[\mathrm{nmol} \mathrm{min}^{-1}(\mathrm{mg} \text { protein })^{-1}\right)\right]\end{array}$} \\
\hline & & & Ammonia & $\begin{array}{c}\text { Nitrogen source: } \\
\text { Nitrate }\end{array}$ & Dinitrogen \\
\hline $\begin{array}{l}\text { Glutamine synthetase } \\
\text { (biosynthetic assay) }\end{array}$ & ATP & $\begin{array}{l}\mathrm{Mg}^{2+} \\
\mathrm{Mn}^{2+}\end{array}$ & $\begin{array}{l}0.94 \\
5.56\end{array}$ & $\begin{array}{l}1 \cdot 07 \\
3 \cdot 81\end{array}$ & $\begin{array}{c}26 \cdot 6 \\
9 \cdot 45\end{array}$ \\
\hline $\begin{array}{l}\text { Glutamine synthetase } \\
\text { (transferase assay) }\end{array}$ & ADP & $\mathrm{Mn}^{2+}$ & 1015 & 1296 & 2673 \\
\hline Glutamate synthase & $\begin{array}{l}\text { NADH } \\
\text { NADPH }\end{array}$ & & $\begin{array}{l}20 \cdot 9 \\
\text { ND }\end{array}$ & $\begin{array}{l}29 \cdot 9 \\
\text { ND }\end{array}$ & $\begin{array}{l}28 \cdot 5 \\
\text { ND }\end{array}$ \\
\hline $\begin{array}{l}\text { Nitrogenase } \\
\text { (acetylene reduction) }\end{array}$ & & & ND & $\mathrm{ND}$ & $5 \cdot 7$ \\
\hline
\end{tabular}

ND, Not detectable.

$1983 a$ ), and was due to differences in the adenylylation state of the enzyme. Adenylylation of GS has been demonstrated in many Gram-negative bacteria (Gancedo \& Holzer, 1968; Tronick $e t$ al., 1973) and Streptomyces cattleya (Streicher \& Tyler, 1981) and is an important mechanism for the regulation of GS activity in these organisms. However, regulation of GS by adenylylation is not universal, as there is no evidence for adenylylation in most Gram-positive bacteria (Gancedo \& Holzer, 1968; Tronick et al., 1973) or in cyanobacteria (Stacey et al., 1979).

The adenylylated and deadenylylated forms of GS differ with respect to catalytic potential and divalent cation specificity in the various reactions catalysed by GS in vitro (Stadtman \& Ginsburg, 1974). The observed effects of cations on both the GS transferase and biosynthetic activities in 'Methylosinus' 6 were consistent with the full adenylylation of GS in ammonia- and nitrate-grown cultures and with little or no adenylylation of GS in dinitrogen-grown cultures. Studies on other Type II methanotrophs have not given any indication that the enzyme might be adenylylated in these organisms (Shishkina \& Trotsenko, 1979; Murrell \& Dalton, 1983b).

Alteration of GS activity by treatment with SVPDE has been used as presumptive evidence for adenylylation of GS (Siedel \& Shelton, 1979; Janssen et al., 1980; Streicher \& Tyler, 1981; Murrell \& Dalton, 1983a). Incubation of cell extracts of ammonia-grown 'Methylosinus' 6 with SVPDE for up to $160 \mathrm{~min}$ did not result in a decrease in the level of inhibition of $\mathrm{Mn}^{2+}$ dependent GS transferase activity by $60 \mathrm{~mm}-\mathrm{Mg}^{2+}$, as would be expected after the removal of adenyl groups from adenylylated GS (Tronick et al., 1973). It is possible that the reaction conditions necessary to remove adenyl groups from 'Methylosinus' 6 GS were not achieved in this experiment. Alternatively, the adenyl groups may have been removed by the treatment used but the transferase assay conditions may not have monitored this change. The first attempts to demonstrate adenylylation in Rhodopseudomonas capsulata were also unsuccessful, but a change in the effect of $\mathrm{Mg}^{2+}$ on $\mathrm{Mn}^{2+}$-dependent transferase activity by SVPDE treatment was later noted (Johansson \& Gest, 1977). Further studies using purified GS are needed to determine whether or not modification of GS does occur in 'Methylosinus' 6, and to determine if this enzyme is different from that in other Type II methanotrophs.

\section{Effects of oxygen tension on carbon and nitrogen metabolism}

A direct study of the relationship between carbon and nitrogen metabolism in 'Methylosinus' 6 was not possible since this isolate could only grow on methane. Previous investigations had shown that oxygen affected nitrogen fixation (de Bont \& Mulder, 1974; Dalton \& Whittenbury, $1976 a, b$; Dalton, 1980; Murrell \& Dalton, 1983c) while other studies indicated that oxygen might be important in the regulation of methane oxidation and the development of the 
intracytoplasmic membrane system (Brannan \& Higgins, 1978; Patt \& Hanson, 1978; Scott et al., 1981; Chetina et al., 1982). In order to assess the effect of $\mathrm{O}_{2}$ on both carbon and nitrogen metabolism in 'Methylosinus' 6, cells were grown in continuous culture under sulphate limitation, with methane as the carbon source and either dinitrogen or nitrate as the nitrogen source, and the effect of the dissolved oxygen tension (DOT) on nitrogen fixation, methane oxidation and the intracytoplasmic membrane content was determined.

With dinitrogen as the nitrogen source, steady-state cultures were established at specific DOTs from 11.8 to $58.8 \mu \mathrm{M}$-oxygen, and acetylene reduction and methane oxidation activities were determined. The methane oxidation rates observed represented potential rather than in situ rates, since the DOT was increased to about $100 \mu \mathrm{M}$ for the purpose of the assay. These values should be considered as maximum rates, and probably reflect the level of active enzyme. Thin sections of cell samples were also examined using an electron microscope to estimate the internal membrane content. Two attempts to establish a steady-state culture at a DOT of $82.5 \mu \mathrm{M}$ were unsuccessful.

Methane oxidation and nitrogen fixation responded to changes in the DOT (Fig. 3). An increase from 11.8 to $23.5 \mu \mathrm{M}-\mathrm{O}_{2}$ resulted in an increase in the rate of acetylene reduction. From 23.5 to $58.8 \mu \mathrm{M}-\mathrm{O}_{2}$, a decrease in the rate of acetylene reduction activity was observed. The rate of methane oxidation increased over the entire DOT range studied. This increase was slight over the 11.8 to $47 \mu \mathrm{M}$ range [from 0.030 to $0.040 \mu \mathrm{mol} \mathrm{min}^{-1}$ (mg protein) ${ }^{-1}$ ] and more substantial from 47 to $58.8 \mu \mathrm{M}-\mathrm{O}_{2}$ [from 0.040 to $0.115 \mu \mathrm{mol} \mathrm{min}^{-1}$ (mg protein) ${ }^{-1}$ ]. The increase in methane oxidation was paralleled by an increase in the internal membrane content of each cell. Cells grown at $11.8,23.5,35.3$ and $47 \mu \mathrm{M}-\mathrm{O}_{2}$ in general contained only one paired unit membrane structure around their periphery, while cells grown at $58.8 \mu \mathrm{M}-\mathrm{O}_{2}$ had two or three paired layers of membranes. The OD at each steady state varied only slightly.

Sulphate-limited chemostat cultures were also established at $11.8,23.5$ and $70.5 \mu \mathrm{M}-\mathrm{O}_{2}$ with nitrate as a nitrogen source. Acetylene reduction activity could not be detected in cells grown under these conditions. We observed the opposite effect of $\mathrm{O}_{2}$ on methane oxidation and intracytoplasmic membrane content as compared with the nitrogen-fixing culture. That is, higher rates of methane oxidation were found at 11.8 and $23.5 \mu \mathrm{M}-\mathrm{O}_{2} \quad[0.146$ and $0.125 \mu \mathrm{mol} \mathrm{min}^{-1}\left(\mathrm{mg}\right.$ protein) $\left.{ }^{-1}\right]$ than at $\left.70.5 \mu \mathrm{M}-\mathrm{O}_{2}\left[0.0315 \mu \mathrm{mol} \mathrm{min}^{-1} \text { (mg protein }\right)^{-1}\right]$.

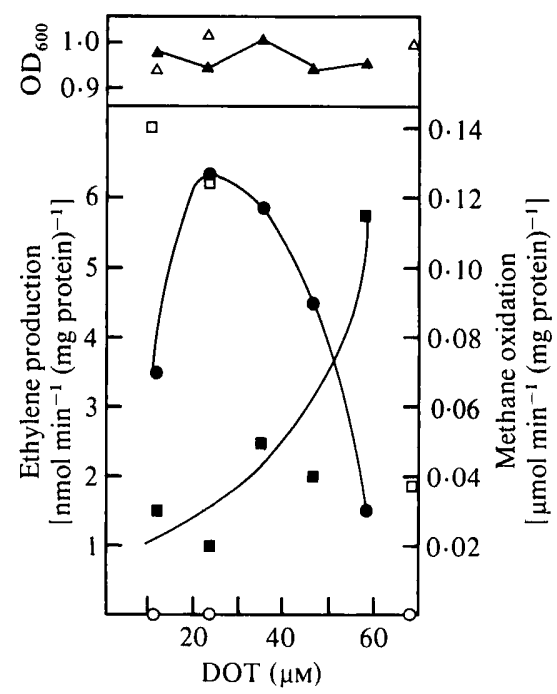

Fig. 3. Methane oxidation and acetylene reduction activities in 'Methylosinus' 6 grown on methane in sulphate-limited continuous culture. Steady-state cultures of 'Methylosinus' 6 were established at various DOTs with either dinitrogen or nitrate as the nitrogen source and assays were carried out on whole cells. Dinitrogen-grown cultures: $\odot$, acetylene reduction; $\boldsymbol{\square}$, methane oxidation; $\mathbf{\Delta}, \mathrm{OD}_{600}$. Nitrate-grown cultures; $O$, acetylene reduction; $\square$, methane oxidation; $\triangle, \mathrm{OD}_{600}$. 
Once again, the rate of methane oxidation was paralleled by the internal membrane content. Two or three paired layers of membranes were seen in cells grown at $11.8 \mu \mathrm{M}-\mathrm{O}_{2}$ while only one paired layer was seen in cells grown at $70 \cdot 5 \mu \mathrm{M}-\mathrm{O}_{2}$. The OD in each of these steady states was within $6 \%$ of that observed in the experiments with nitrogen-fixing cultures.

We were not surprised to observe negative regulation of the methane oxidation rate and the intracytoplasmic membranes by increasing DOT in the nitrate cultures, since this had also been found in batch cultures of 'Methylosinus trichosporium' OB3b (Brannan \& Higgins, 1978) and Methylomonas methanica (Chetina et al., 1982). However, our results suggest that in 'Methylosinus' 6 the response of methane oxidation to DOT is not constant, but rather is dependent upon the nitrogen source.

Several possible explanations exist for our observations. The trivial explanation, that conditions other than the nitrogen source changed, does not appear to be valid since optical densities, growth rates and the growth-limiting nutrient were always constant. Therefore, it seems that nitrogen metabolism does influence carbon metabolism, either indirectly through other cellular processes, or through a direct interaction between methane oxidation and nitrogen fixation. The influence could reflect transcriptional regulation, resulting in different protein levels, or regulation at the level of enzyme activity, either by allosteric effectors or substrate limitation.

Since methane oxidation was roughly paralleled by the intracytoplasmic membrane content in cultures grown with either nitrate or dinitrogen, it is possible that nitrogen metabolism influenced carbon metabolism indirectly by regulating membrane formation. In Methylomonas methanica utilization of ammonia or nitrate did not influence intracytoplasmic membrane content (Chetina et al., 1982).

It is possible that the variation we observed reflected a changing ratio of two different methane monooxygenase (MMO) enzymes. If two different enzymes were present, they might have different activities, and so a switchover from one to the other could result in a change in total methane oxidation. In 'Methylosinus trichosporium' OB3b, variation in the amount of intracytoplasmic membranes was correlated with variation in the amount of particulate versus soluble MMO purified (Scott et al., 1981). This variation has been shown to depend on the ratio of the copper concentration to the total biomass (Stanley et al., 1983). In Methylococcus capsulatus Bath, copper to biomass ratios of less than 1-3 $\mu \mathrm{mol}$ per g dry weight resulted in the appearance of the soluble enzyme, while ratios greater than this resulted in predominance of the particulate enzyme. Under oxygen limitation, copper stress occurred at a higher copper to biomass ratio than under methane limitation. Evidence was presented suggesting that the particulate and soluble MMOs were different enzymes (Stanley et al., 1983). Qualitatively similar results were obtained for 'Methylosinus trichosporium' OB3b, but preliminary evidence suggested that only one MMO was present in 'Methylomonas albus' BG8.

It is not known whether 'Methylosinus' 6 contains two different MMOs, since we were not able to obtain stable MMO activity in extracts using a propylene assay. However, it seems likely, since in other methanotrophs the relative amount of the intracytoplasmic membranes is indicative of the ratio of soluble to particulate MMO. The copper to biomass ratio in our chemostat experiments was $0 \cdot 2 \mu \mathrm{mol}$ per $\mathrm{g}$ dry weight, but it is not known if this represented copper stress under these conditions. If two MMOs do exist in this strain, then it is possible that the switchover from low to high membrane content was accompanied by a change in the predominant $\mathrm{MMO}$, thereby changing the total methane oxidation activity.

Oxygen has been shown to affect both nitrogenase synthesis and stability in all nitrogen-fixing bacteria studied (Robson \& Postgate, 1980). The decrease seen in acetylene reduction activity of cultures grown at 47 and $58.8 \mu \mathrm{M}-\mathrm{O}_{2}$ and the failure to establish steady-state cultures on dinitrogen at $82.3 \mu \mathrm{M}-\mathrm{O}_{2}$ suggested that the nitrogenase in 'Methylosinus' 6 was also sensitive to $\mathrm{O}_{2}$. Therefore, another explanation for the increased rate of methane oxidation found in cells grown at these two dissolved oxygen levels could involve competition between nitrogenase and MMO for sulphur or reducing power. At higher DOTs less nitrogenase would be active, and the subsequent decreased competition could result in increased MMO activity either through transcriptional regulation or an in vivo limitation. 
The mechanism whereby nitrogen metabolism regulates the response of intracytoplasmic membranes and methane oxidation to oxygen in 'Methylosinus' 6 is an intriguing problem. Our data suggest that oxygen itself must not be the regulatory element, but rather some cellular component that responds to oxygen and does so differently under nitrogen-fixing conditions than under non-nitrogen-fixing conditions. The differences between nitrogen-fixing cells and non-nitrogen-fixing cells would include an increased demand for energy and reducing power as well as an increased demand for sulphur, which could be significant in a sulphate-limited culture. Therefore, the most likely controlling elements would be energy charge, reducing power and sulphur. However, further studies will be necessary to determine whether any of these possibilities is correct. The shape of the curves in Fig. 3 suggests that this interaction reflects a combination of regulatory events rather than a single process. Since no other similar studies have been conducted in other methanotrophs using dinitrogen as the nitrogen source, the generality of this influence of nitrogen metabolism on methane oxidation at varying oxygen concentrations cannot be evaluated at this time, but it may reflect unique aspects of regulation in methanotrophs.

This work was supported by a grant from the US Department of Agriculture (no. 59-2532-1-1-711-0). A. T. was supported by a predoctoral traineeship from the National Institutes of Health (GM 07270). We would like to thank L. Lehmicke for carrying out the ribulosebisphosphate carboxylase assays and J. C. Murrell for many helpful discussions.

\section{REFERENCES}

ANTHONY, C. (1982). The Biochemistry of Methylotrophs. London: Academic Press.

Bailey, M. L., Downs, J. \& Drozd, J. W. (1978). Nitrogen metabolism in Methylococcus NCIB 11083. Proceedings of the Society for General Microbiology 5, 65-66.

Blackmore, M. A. \& QUaYle, J. R. (1970). Microbial growth on oxalate by a route not involving glyoxylate carboligase. Biochemical Journal 118, 53-59.

DE BoNT, J. A. M. \& MuLdeR, E. G. (1974). Nitrogen fixation and co-oxidation of ethylene by a methaneutilizing bacterium. Journal of General Microbiology 83, 113-121.

DE BoNT. J. A. M. \& Mulder, E. G. (1976). Invalidity of the acetylene reduction assay in alkane-utilizating, nitrogen-fixing bacteria. Applied and Environmental Microbiology 31, 640-647.

BranNan, J. \& Higgins, I. J. (1978). Effect of growth conditions on the intracytoplasmic membranes of Methylosinus trichosporium OB3b. Proceedings of the Society of General Microbiology 5, 69.

Chetina, E. V., Suzina, N. E., Fikhte, B. A. \& TROTSENKo, YU. A. (1982). Influence of culture conditions on organization of the membrane apparatus in Methylomonas methanica. Mikrobiologiya 51, 247-254.

Colby, J., Dalton, H. \& Whittenbury, R. (1975). An improved assay for bacterial methane monooxygenase: some properties of the enzyme from Methylomonas methanica. Biochemical Journal 151, 459-462.

DaHL, J. S., Mehta, R. J. \& Hoare, D. S. (1972). New obligate methylotroph. Journal of Bacteriology 109 , 916-921.

Dalton, H. (1977). Ammonia oxidation by the methane oxidising bacterium Methylococcus capsulatus strain Bath. Archives of Microbiology 114, 273279.
Dalton, H. (1980). Chemoautotrophic nitrogen fixation. In Proceedings of the Phytochemical Society of Europe Symposium, Vol. 18, pp. 177-196. Edited by W. D. P. Stewart \& J. R. Gallon. London: Academic Press.

Dalton, H. \& Whittenbury, R. (1978a). The acetylene reduction technique as an assay for nitrogenase activity in the methane oxidizing bacterium Methylococcus capsulatus strain Bath. Archives of Microbiology 109, 147-151.

Dalton, H. \& Whittenbury, R. (1976b). Nitrogen metabolism in Methylococcus capsulatus (strain Bath). In Microbial Production and Utilization of Gases, pp. 379-388. Göttingen: Akademie der Wissenschaften zu Göttingen.

Davey, J. F., WhitTenbury, R. \& Wilkinson, J. F. (1972). The distribution in methylobacteria of some key enzymes concerned with intermediary metabolism. Archiv für Mikrobiologie 87, 359-366.

Drozd, J. W., Godley, A. \& Bailey, M. L. (1978). Ammonia oxidation by methane-oxidising bacteria. Proceedings of the Society for General Microbiology 5 , 66-67.

Foster, J. W. \& DAVIS, R. H. (1966). A methanedependent coccus, with notes on classification and nomenclature of obligate, methane-utilizing bacteria. Journal of Bacteriology 91, 1924-1931.

GaNCEDo, C. \& Holzer, H. (1968). Enzymatic inactivation of glutamine synthetase in Enterobacteriaceae. European Journal of Biochemistry 4, 190192.

Ginsburg, A., Yeh, J., Henning, S. B. \& Denton, M. D. (1970). Some effects of adenylylation on the biosynthetic properties of the glutamine synthetase from Escherichia coli. Biochemistry 9, 633-648.

Higgins, I. J., Hammond, R. C., Sariaslani, F. S., Best, D., Dayies, M. M., Tryhorn, S. E. \& TAYlor, F. (1979). Biotransformation of hydrocarbons and 
related compounds by whole organism suspension of methane-grown Methylosinus trichosporium OB3b. Biochemical and Biophysical Research Communications 89, 671-677.

Higgins, I. J., Best, D. J., Hammond, R. C. \& ScotT, D. (1981). Methane-oxidizing microorganisms. Microbiological Reviews 45, 556-590.

Janssen, D. B., HubB, J. M., Leenen, P. J. M. \& VAN DER DRIFT, C. (1980). The enzymes of ammonia assimilation of Pseudomonas aeruginosa. Archives of Microbiology 124, 197-203.

Johansson, B. C. \& GeST, H. (1977). Adenylylation/ deadenylylation control of glutamine synthetase of Rhodopseudomonas capsulata. European Journal of Biochemistry 81, 365-371.

JoHNSON, J. L. (1981). Genetic characterizations. In Manual of Methods of General Bacteriology, pp. 450472. Edited by $P$. Gerhardt, Washington, DC: American Society for Microbiology.

LARGE, P. J. \& QUAYLE, J. R. (1963). Microbial growth on $C_{1}$ compounds. 5. Enzyme activities in extracts of Pseudomonas AM1. Biochemical Journal 87, 386395.

LaWrence, A. J. \& QuAYle, J. R. (1970). Alternative carbon assimilation pathways in methane-utilizing bacteria. Journal of General Microbiology 63, 371374.

LAYNE, E. (1957). Spectrophotometric and turbidimetric methods for measuring proteins. Methods in Enzymology 3, 447-454.

LePo, J. R., Wyss, O. \& TABITA, F. R. (1982). Regulation and biochemical characterization of the glutamine synthetase of Azotobacter vinelandii. Biochimica et biophysica acta 704, 414-421.

LYNCH, M. J., Wopat, A. E. \& O'CONNOR, M. L. (1980). Characterization of two new facultative methanotrophs. Applied and Environment Microbiology 40, 400-407.

MARMUR, J. (1961). A procedure for the isolation of deoxyribonucleic acid from microoganisms. Journal of Molecular Biology 3, 208-218.

Murrell, J. C. \& Dalton, H. (1983a). Purification and properties of glutamine synthetase from Methylococcus capsulatus (Bath). Journal of General Microbiology 129, 1187-1196.

Murrell, J. C. \& Dalton, H. (1983b). Ammonia assimilation in Methylococcus capsulatus (Bath) and other obligate methanotrophs. Journal of General Microbiology 129, 1197-1206.

Murrell, J. C. \& Dalton, H. (1983c). Nitrogen fixation in obligate methanotrophs. Journal of General Microbiology 129, 3481-3486.

Nicholas, D. J. D. \& Nason, D. (1957). Determination of nitrate and nitrite. Methods in Enzymology 3, 981-984

O'CONNOR, M. L. \& HANSON, R. S. (1978). Linkage relationships between mutants of Methylobacterium organophilum impaired in their ability to grow on one-carbon compounds. Journal of General Microbiology 104, 105-111.

PatT, T. E. \& Hanson, R. S. (1978). Intracytoplasmic membranes, phospholipid, and sterol content of Methylobacterium organophilum cells grown under different conditions. Journal of Bacteriology 134, 636-644.

Portnoy, D. A., Moseley, S. L. \& Falkow, S. (1981). Characterization of plasmids and plasmid-associat- ed determinants of Yersinia enterocolitica pathogenesis. Infection and Immunity 31, 775-782.

Robson, R. L. \& Postgate, J. R. (1980). Oxygen and hydrogen in biological nitrogen fixation. Annual Reviews of Microbiology 34, 183-207.

Scott, D., Brannan, J. \& Higgins, I. J. (1981). The effect of growth conditions on intracytoplasmic membranes and methane monooxygenase activities in Methylosinus trichosporium OB3b. Journal of General Microbiology 125, 63-72.

Shishkina, V. N. \& Trotsenko, YU. A. (1979). Pathways of ammonia assimilation in obligate methane utilizers. FEMS Microbiology Letters 5, 187-191.

Siedel, J. \& Shelton, E. (1979). Purification and properties of Azotobacter vinelandii glutamine synthetase. Archives of Biochemistry and Biophysics 192, 214-224.

Sokolov, I. G., Romanovskaya, V. A., ShKurko, YU. B. \& MalashenKo, YU. R. (1980). Comparative characterization of the enzyme systems of methaneutilizing bacteria that oxidize $\mathrm{NH}_{2} \mathrm{OH}$ and $\mathrm{CH}_{3} \mathrm{OH}$. Mikrobiologiya 49, 202-209.

Stacey, G., Van Baalen, C. \& Tabita, F. R. (1979). Nitrogen and ammonia assimilation in the cyanobacteria: regulation of glutamine synthetase. Achives of Biochemistry and Biophysics 194, 457-467.

Stadtman, E. R. \& GinsburG, A. (1974). The glutamine synthetase of Escherichia coli: structure and control. In The Enzymes, vol. 10, 3rd edn, pp. 755-807. Edited by P. D. Boyer. New York: Academic Press.

Stanley, S. H., Prior, S. D., Leak, D. J. \& Dalton, H. (1983). Copper stress underlies the fundamental change in intracellular location of methane monooxygenase in methane-oxidizing organisms: studies of batch and continuous cultures. Biotechnology Letters 5, 487-490.

STREICHER, S. L. \& TYLER, B. (1981). Regulation of glutamine synthetase activity by adenylylation in the Gram-positive bacterium Streptomyces cattleya. Proceedings of the National Academy of Sciences of the United States of America 78, 229-233.

Tabita, F. R., Caruso, P. \& Whitman, W. (1978). Facile assay of enzymes unique to the Calvin cycle in intact cells, with special reference to ribulose 1,5bisphosphate carboxylase. Analytical Biochemistry 84, 462-472.

Tronick, S. R., Ciardi, J. E. \& Stadtman, E. R. (1973). Comparative biochemical and immunological studies of bacterial glutamine synthetases. Journal of Bacteriology 115, 858-868.

WhitTEnBURY, R. \& DALTON, H. (1981). The methylotrophic bacteria. In The Prokaryotes, vol. 1, pp. 894 902. Edited by M. P. Starr, H. Stolp, H. G. Trüper, A. Balows \& H. G. Schlegel. New York: SpringerVerlag.

Whittenbury, R., Phillips, K. C. \& Wilkinson, J. F. (1970). Enrichment, isolation and some properties of methane-utilizing bacteria. Journal of General Microbiology 61, 205-218.

Wolfe, R. S. \& Higgins, I. J. (1979). Microbial biochemistry of methane - a study of contrasts. Part 2: Methanotrophy. In International Review of Biochemistry, Microbial Biochemistry, vol. 21, pp. $300-$ 353. Edited by J. R. Quayle. Baltimore: University Park Press. 